\author{
ANNA LUBIŃSKA \\ Uniwersytet Wrocławski
}

\title{
Stanisława Przybyszewskiego kontakty z polskimi wydawcami
}

Współpraca wydawcy z autorem nie zawsze układa się bezproblemowo. Za pomyślność takich kontaktów na pewno odpowiadają obie strony. Co jednak w sytuacji, gdy do wydawcy przychodzi listownie wyznanie o treści:

Dziś skończyłem 35 rok mego życia, 23 maja tego samego roku będę obchodził jubileusz piętnastoletniej pracy literackiej, wybacz Pan, że się do niego znowu z prośbą zwracam, ale strasznie przykro człowiekowi w tak podniosłych dniach być bez kopiejki, a raczej już drugi dzień bez obiadu [...]. Zrobiłby mi Pan ogromną przysługę, gdyby mi Pan pożyczył 10 rubli ${ }^{1}$

Albo pretensje podobne do tych:

Uprzedzam Panów, że praw, z których wszyscy korzystają, ja specjalnie wyzbywać się nie będę i nie mogę. Jeżeli zaś nakładowi Panów na tem zależy, by i nadal wydać moje rzeczy, w takim razie pozostaje jedna tylko alternatywa: albo zgodzicie się Panowie na to, że będę uprzednio moje utwory drukował w pismach, albo też w przeciwnym razie powiększycie mi honorarium² ${ }^{2}$.

Stanisław Przybyszewski (1868-1927), autor zacytowanych fragmentów, z pewnością nie należał do łatwych współpracowników. Dzieje wydawnicze utworów pisarza pełne były wzlotów i upadków, a jego kariera i kontakty z właścicielami oficyn — burzliwe. Mimo to dzieła Przybyszewskiego wydawane były w ważnych i znaczących polskich wydawnictwach przełomu XIX i XX wieku, między innymi w Księgarni Polskiej, Gebethnerze i Wolffie oraz Lektorze, a autor nawiązywał współpracę z takimi wydawcami, jak Stefan Demby czy Bolesław Hozakowski. Charakter kontaktów Przybyszewskiego z wydawcami jest

${ }^{1}$ S. Przybyszewski, Listy, t. 1, 1879-1906, zebrał, życiorysem, wstępem i przypisami opatrzył S. Helsztyński, Gdańsk 1937, s. 306 [List do Stefana Dembego w Warszawie z dnia 30 kwietnia 1903].

2 S. Przybyszewski, Listy, t. 2, 1906-1917, zebrał, życiorysem, wstępem i przypisami opatrzył S. Helsztyński, Gdańsk 1938, s. 511-512 [List do firmy Gebethner i Wolff w Warszawie z dnia 1 września 1911]. 
dziś możliwy do prześledzenia dzięki listom pisarza, opracowanym i zebranym w trzech tomach przez Stanisława Helsztyńskiego ${ }^{3}$.

Przybyszewski znany jest przede wszystkim jako twórca powieści, poematów prozą, rozpraw i tekstów dramatycznych. Inspirację dla twórczości tego słynnego modernisty wielokrotnie stanowiło jego bujne życie uczuciowe, co tylko podsycało zainteresowanie samymi dziełami. Ciekawość budziły jednak nie tylko sprawy osobiste i burzliwe związki z kolejnymi kobietami, lecz także poglądy estetyczne, które wyróżniały go spośród współczesnych mu twórców. To właśnie on był najbardziej zagorzałym propagatorem haseł „sztuka dla sztuki” i „,naga dusza”, a także autorem słynnego młodopolskiego manifestu Confiteor.

Wywoływał skrajne uczucia: był jednocześnie wielbiony i krytykowany, fascynował i oburzał. Zarówno za życia, jak i po śmierci wzbudzał wiele kontrowersji i przez długi czas pozostawał na językach współczesnych mu literatów i artystów. Na jego temat wypowiadali się niemal wszyscy, zarówno ci, którzy zetknęli się z nim osobiście, jak i ci, do których docierały tylko plotki. Jakub Geszwind celnie zauważył, że na pisarzu „ciążyła [...] jakby klątwa lekkomyślności sądów ludzkich, i to nie tylko pochodzących z kół czytającej publiczności, ale też i z kół krytyków i przyjaciół”4 . Wydaje się, że pisarz sam prowokował sprzeczne opinie na swój temat, tworząc różne mity i kreując własną legendę. Mimo licznych opracowań i pracy wielu badaczy, którzy zgłębiali jego dorobek i życie prywatne, nadal trudno określić, które szczegóły są faktami, a które jedynie legendą. Artur Hutnikiewicz zauważył, że „o Przybyszewskim nic się porządnie nie wie, jakim był naprawdę i co wniósł do dorobku naszej kultury, ponieważ między nami a nim rozrosła się niesamowicie jakaś zła i krzywdząca legenda"5.

Nietuzinkowa biografia, pokaźna spuścizna literacka, a także wpływ, jaki dzieła Stanisława Przybyszewskiego miały na rozwój literatury modernistycznej sprawiają, że jest on wciąż interesującym tematem naukowych dociekań. Jego twórczość i barwna biografia może być źródłem interesujących odkryć nie tylko stricte literackich, lecz także bibliologicznych.

Dzieje wydawnicze utworów Stanisława Przybyszewskiego w Polsce zaczynają się w 1899 roku od poematu prozą Nad morzem. Ten niewielki objętościowo tekst drukowany był na łamach krakowskiego „Życia”, a w formie zwartej został wydany jako czterdziestodziewięciostronicowy druk przez krakowski oddział G. Gebethner i Sp. Autorem opracowania typograficznego publikacji był Stanisław Wyspiański.

Wydawnictwo Gebethner i Wolff zostało założone przez Gustawa Adolfa Gebethnera (1831-1901) i Augusta Roberta Wolffa (1833-1910) w 1857 roku w War-

${ }^{3}$ Zob. S. Przybyszewski, Listy, t. 1; idem, Listy, t. 2; idem, Listy, t. 3, 1918-1927, zebrał, życiorysem, wstępem i przypisami opatrzył S. Helsztyński, Wrocław 1954.

${ }^{4}$ J. Geszwind, Kłamstwo Przybyszewskiego i kłamstwa o Przybyszewskim, Lwów 1928, s. 8.

5 A. Hutnikiewicz, Stanisław Przybyszewski. Legenda i rzeczywistość, [w:] idem, Portrety i zarysy literackie, Warszawa 1976, s. 44. 
szawie i publikowało głównie klasyków literatury polskiej, takich jak Henryk Sienkiewicz, Władysław Reymont, Bolesław Prus i Eliza Orzeszkowa ${ }^{6}$. Obok literatury pięknej w repertuarze wydawniczym oficyny można było znaleźć także podręczniki, literaturę dla dzieci i młodzieży, dzieła humanistyczne i teologiczne oraz czasopisma. Wydawnictwo prowadziło hurtowy i detaliczny handel książką, i działało w kilku filiach poza Warszawą: w Krakowie, Łodzi, Poznaniu, Wilnie i Zakopanem ${ }^{7}$. Cechą charakterystyczną książek, które wychodziły spod pras Gebethnera i Wolffa był ich wysoki poziom estetyczny, cechujący się — jak określił to Janusz Sowiński — „zachowaniem równowagi pomiędzy wyczuciem i uznaniem wartości publikowanych dzieł a metodami ich materializacji graficznej"8.

Przybyszewski swoją karierę w Polsce rozpoczął od wydania Nad morzem właśnie u Gebethnera i Wolffa, jednak stała współpraca pomiędzy firmą a pisarzem nawiązała się dopiero po kilku latach, w 1907 roku, kiedy wydawnictwo to opublikowało jeden z najbardziej cenionych dramatów pisarza, Śnieg. Było to drugie wydanie sztuki, która zadebiutowała wydawniczo w 1903 roku w oficynie Stefana Dembego.

W pierwszych latach pobytu w Polsce Przybyszewski związał się zawodowo z Księgarnią Polską. Istniejącą od 1872 roku „księgarnię antykwarnię, wypożyczalnię nut, ajencję dzienników i skład utworów sztuk pięknych" nabył od jej właścicielki, Lei Klotyldy Bartoszewiczowej, w 1889 roku Bernard Połoniecki (1862-1943) i rozpoczął w niej działalność wydawniczą ${ }^{9}$. Publikował głównie literaturę piękną, a w jego ofercie znalazły się teksty wybitnych przedstawicieli Młodej Polski: Karola Irzykowskiego, Jana Kasprowicza, Kornela Makuszyńskiego, Adolfa Nowaczyńskiego, Gabrieli Zapolskiej i wielu innych. Nakładem Księgarni Polskiej ukazały się także wydania krytyczne dzieł Adama Mickiewicza, Juliusza Słowackiego, Aleksandra Fredry i Williama Shakespeare'a ${ }^{10}$.

Ze wspomnień Połonieckiego wynika, że stosunki pomiędzy nim a Przybyszewskim znacznie wykraczały poza oficjalne kontakty zawodowe. Wydawca wspomina, że po przeniesieniu się Przybyszewskiego z Krakowa do Lwowa pomagał mu on urządzić się w mieście:

Ponieważ byłem stałym jego wydawcą, zająłem się urządzeniem jego stosunków życiowych na gruncie lwowskim. Miał zapewnione mieszkanie i niewielkie dochody, wystarczające na skromne życie. A potrzeby jego były bardzo skromne, tylko należało zawsze dbać o jego najkonieczniejsze potrzeby, o które sam wcale nie dba $1^{11}$.

${ }^{6}$ K. Maleczyńska, Książki i biblioteki w Polsce okresu zaborów, Wrocław 1987, s. 15.

${ }^{7}$ N. Kraśko, Instytucje wydawnicze w II Rzeczypospolitej, Warszawa 2001, s. 30.

8 J. Sowiński, Typografia wytworna w Polsce 1919-1939, Wrocław 1995, s. 13.

${ }_{9}^{9}$ Bernard Połoniecki księgarz lwowski. Dzienniki, pamiętniki i listy z lat 1880-1943, opracowała i wstępem opatrzyła M. Konopka, Warszawa 2006, s. 18-19.

${ }^{10}$ Ibidem, s. 22-23.

11 B. Połoniecki, Ze wspomnień wydawcy, „Prosto z Mostu” 1935, nr 41, s. 3. 
Połoniecki zobowiązał się jednocześnie wypłacać Przybyszewskiemu stałe sumy na poczet tworzonych przez niego utworów pod warunkiem, że ten sumiennie będzie je pisal. $\mathrm{Z}$ taką zachętą i sprzyjającą do systematycznej pracy lwowską atmosferą ${ }^{12}$, Przybyszewskiemu udało się w ciągu roku napisać cztery dramaty (cykl dramatyczny Taniec miłości i śmierci oraz Matkę), a także początek powieści Synowie ziemi. Swój pomysł Połoniecki ocenił po latach: „Eksperyment ten bajecznie mi się udał"13. Podobnym systemem wydawca płacił jeszcze Stanisławowi Brzozowskiemu i Władysławowi Orkanowi. Praktyki te różnie były oceniane przez innych pisarzy. Jan Kasprowicz uważał, że Połoniecki płaci zbyt skromne kwoty, Leopold Staff krytykował natomiast jego opieszałość w kwestii wypłacania honorarium ${ }^{14}$.

Z utworów Przybyszewskiego w Księgarni Polskiej ukazały się: Z cyklu wigilii $(1899,1901)$, Dzieci szatana $(1899,1907)$, Dla szczęścia $(1900,1902)$, Taniec miłości i śmierci (1901, 1902), cyk1 Homo sapiens (1901), Matka (1903), Requiem aeternam (1904) oraz Synowie ziemi (1904).

Ciekawie przedstawiają się losy kontaktów wydawniczych Przybyszewskiego ze Stefanem Dembym (1862-1939), czyli kolejnym wydawcą, z którym utrzymywał długotrwałą współpracę. Demby, znany dziś przede wszystkim jako twórca i pierwszy dyrektor Biblioteki Narodowej, był wielkim miłośnikiem książek. Nauczyciel, bibliograf, wydawca, redaktor, pisarz, bibliotekarz, bibliofil - to określenia, którymi najczęściej jest przedstawiana jego postać ${ }^{15}$. W zamiłowaniu do książki towarzyszyła mu idea odrodzenia książki pięknej, która widoczna była zwłaszcza w jego działalności wydawniczej prowadzonej w latach 1899-1906 ${ }^{16}$. Bogdan Klukowski wylicza, że w ciągu tych siedmiu lat nakładem Dembego ukazało się prawdopodobnie trzydzieści siedem tytułów książkowych ${ }^{17}$. Założona i kierowana przez Dembego oficyna nazywana była Księgarnią Sortymentowo-Wydawniczą lub Księgarnią Nakładową ${ }^{18}$, a styl wyróżniający jej wydawnictwa stanowiły motywy ozdobne charakterystyczne dla zdobień młodopolskich, duże formaty, wytworny, czerpany papier oraz bogato zdobione okładki, projektowane niekiedy przez samego Dembego ${ }^{19}$. Wiele wskazuje też na to, że sam zajmował się on redakcją wydawanych książek, na co dowodem mogą być listy od Przybyszewskiego ${ }^{20}$.

12 Połoniecki ocenił, że „pobyt we Lwowie służył mu, bo nie było tu notorycznego popijania jak w Krakowie".

13 B. Połoniecki, op. cit., s. 3.

${ }^{14}$ Bernard Połoniecki księgarz lwowski..., s. 23.

15 D. Rymsza-Zalewska, Stefan Demby znany i nieznany, Warszawa 2003, s. 7.

16 Ibidem, s. 9.

${ }^{17}$ B. Klukowski, Stefan Demby —życie petne książek, „Poradnik Bibliotekarza” 2014, nr 10, s. 27.

18 D. Rymsza-Zalewska, Stefan Demby. Ksiegarz i wydawca, Warszawa 2014, s. 9.

${ }^{19}$ Ibidem, s. 14-15.

${ }^{20} \mathrm{~W}$ listach Przybyszewski często informował, że odsyła przejrzaną korektę albo prosi wydawcę o jej wykonanie, na przykład: „Odsyłam korektę [Śniegu], tylko proszę Pana zwrócić bacz- 
W kontekście relacji Dembego ze Stanisławem Przybyszewskim wydawcę często określa się jako entuzjastę i mecenasa twórczości tego kontrowersyjnego modernisty. Danuta Rymsza-Zalewska w monografii Stefan Demby. Ksiegarz $i$ wydawca zauważa nawet, że przyszły dyrektor Biblioteki Narodowej pozostawał pod urokiem Przybyszewskiego i miał nadzieję za sprawą jego utworów rozsławić swoje wydawnictwo ${ }^{21}$. Nie ulega wątpliwości, że to właśnie zachęty i zaliczki udzielane mu przez Dembego umożliwiły pisarzowi powrót do twórczości, gdy ten, osiadłszy już w Warszawie z drugą żoną, Jadwigą Przybyszewską, był w słabej kondycji fizycznej i materialnej. Przybyszewski zajmował się wówczas nie tylko własną, autorską twórczością, lecz także działalnością przekładową. Bogata korespondencja autora $\mathrm{z}$ wydawcą doskonale odzwierciedla relacje pomiędzy mężczyznami, lecz możemy ją poznać tylko z jednej perspektywy — listów, które wysyłał do wydawcy Przybyszewski. W 2004 roku wydane zostały także listy Stefana Dembego ${ }^{22}$, jednak ze względu na brak zachowanej korespondencji kierowanej przez wydawcę do Przybyszewskiego, publikacja ta nie poszerza obrazu relacji pomiędzy nimi.

Prawdopodobnie pierwszy kontakt z pisarzem Demby nawiązał, kiedy zaczął pracować nad Słownikiem pisarzy polskich, który miał być publikacją opartą na „oryginalnych źródłach i dokumentach autobiograficznych zdobytych drogą ankiet, odezw, korespondencji i kontaktów osobistych"23. Jednym ze sposobów pozyskiwania materiałów do publikacji było wysyłanie listownie próśb do literatów o napisaną własnoręcznie autobiografię wraz z dorobkiem literackim i podpisaną fotografią ${ }^{24}$. Planowany słownik pojawił się na półkach księgarskich w 1901 roku. Zatytułowany został Album pisarzy polskich (współczesnych) i stanowił kontynuację wydanego w 1898 roku Albumu pisarzy polskich, który przedstawiał portrety i życiorysy najwybitniejszych polskich pisarzy od X do XIX wieku. Seria nowa, jak określał ją Demby, prezentowała współczesnych literatów, przez co rozumiał on tych, którzy żyli w czasie wydawania albumu. W przedmowie do zbioru Demby zaznaczył, że większość opublikowanych życiorysów ukazała się dzięki uprzejmości samych pisarzy, którzy dostarczyli mu materiały biograficzne i bibliograficzne. Również Przybyszewski spełnił prośbę wydawcy i przesłał mu listownie potrzebne informacje. Swoją opowieść, zaczynającą się od urodzenia w małym Łojewie pod Kruszwicą, zakończył on wówczas osobliwą prośbą: „Tylko Pan nie pisz, że piję za wiele, boby to mo-

ną uwagę na miejsca, w których zbyt długie dialogi ożywiłem [...]. Proszę Pana usilnie o drugą korektę drugiej połowy drugiego arkusza" - S. Przybyszewski, Listy, t. 1, s. 307 [List do Stefana Dembego w Warszawie z maja 1903?].

${ }^{21}$ Ibidem, s. 48.

22 S. Demby, Listy, oprac. D. Rymsza-Zalewska, Warszawa 2004.

23 D. Rymsza-Zalewska, Stefan Demby znany..., s. 55.

${ }^{24}$ Ibidem. 
jej matce, którą kocham nad życie, wielką przykrość sprawiło”25. Opracowana przez Dembego krótka notatka poświęcona Przybyszewskiemu skupiała się wokół tematów związanych z jego edukacją i twórczością. Wspomniane zostały więc szkoły, które pisarz ukończył, opublikowane utwory jego autorstwa oraz zapowiedź znajdującego się $\mathrm{w}$ druku tomu nowel ${ }^{26}$. Oprócz Przybyszewskiego swoje życiorysy wysłali Dembemu między innymi Jan Kasprowicz, Henryk Sienkiewicz, Bolesław Prus oraz Karol Brzozowski, poeta i ojciec Stanisława i Wincentego Korab-Brzozowskich.

Stała współpraca pisarza z Dembym rozpoczęła się w 1902 roku. Początkowo sprowadzała się do zlecania Przybyszewskiemu przekładu utworów niemieckojęzycznych. Doskonale władający tym językiem pisarz tłumaczył między innymi dzieła Johannesa Schlafa czy Alfreda Momberta. Sposób, w jaki przekładał teksty, budzi jednak pewne wątpliwości. W jednym z listów do Dembego oznajmił bowiem:

Kilkanaście stron z książki Momberta nie tłomaczę, bo Mombert począł sam siebie powtarzać i majaczyć. Zresztą znudziło mi się obcych autorów przetwarzać, chociażby i najsilniejszych i na razie zbieram się do mego dramatu ${ }^{27}$.

W 1902 roku Przybyszewski zaoferował Dembemu „na wyłączną własność”28 swój najnowszy dramat, Matkę. W korespondencji prowadzonej między nimi na przestrzeni lat przewijają się tytuły pięciu tekstów literata: wspomnianego już dramatu Matka, Król (znany później jako Odwieczna baśń), Śnieg, Kilka uwag o dramacie oraz Srebrne gody. Ostatecznie został wydany u Dembego tylko jeden utwór Przybyszewskiego, dramat Śnieg. Rachunek za niego opiewał na sumę 480 rubli, a edycja przygotowana została jako druk bibliofilski, opatrzony staranną szatą graficzną i wydany na grubym papierze oraz w dużym formacie $(22 \times 17 \mathrm{~cm})^{29}$.

Współpraca Przybyszewskiego z Dembym na ogół układała się dobrze, czasami jednak dochodziło pomiędzy nimi do spięć na tle finansowym. Prośby autora o zaliczki były częste, a wydawca nierzadko otrzymywał listy o podobnej treści:

Kochany Panie, zechce Pan wyrządzić mi tę wielką przysługę i przez oddawcę niniejszego listu nadesłać mi 10 rubli. Kończę dla Pana w tych dniach całą książkę — która wreszcie będzie gotowa jedna i druga [przekł. Schlafa i Momberta] ${ }^{30}$.

Cztery dni później Przybyszewski wysłał list o podobnej treści:

25 S. Przybyszewski, Listy, t. 1, s. 220 [List do Stefana Dembego w Warszawie z dnia 28 maja 1899].

${ }^{26}$ Album pisarzy polskich (współczesnych), zebrał i objaśnił S. Demby, Warszawa 1901, s. [119], https://polona.pl/item/1111848/3/ [dostęp: 18.03.2017].

27 Ibidem, s. 277 [List do Stefana Dembego w Warszawie z dnia 6 maja 1902].

28 Ibidem, s. 276 [List do Stefana Dembego w Warszawie z dnia 16 kwietnia 1902].

29 D. Rymsza-Zalewska, Stefan Demby. Księgarz..., s. 49-50.

${ }^{30}$ S. Przybyszewski, Listy. t. 1, s. 276 [List do Stefana Dembego w Warszawie z 2 maja 1902]. 
Jeżeli Kochany Pan zechce mieć mój dramat w jak najbliższym czasie, to niech mi pan na te kilka dni tych przeklętych świąt zabezpieczy spokój, bo gubernialna kasa zamknięta i w skutek tego odnoszę się do Pana z błagalną prośbą o przysłanie mi 10 rubli $^{31}$.

Kolejne listy tego rodzaju zwykle nie różniły się od siebie, a zwiększały jedynie nacechowanie emocjonalne, na przykład:

Jeżeli ma Pan trochę litości dla człowieka znajdującego się we wściekłym rozpędzie twórczym, nad człowiekiem który pracy swej przerywać nie chce by latać jak ogar po mieście i szukać pieniędzy, to i Panu i mnie na dobre wyjdzie, jeżeli Pan zechce [...] 10 rubli przysłać ${ }^{32}$.

Pisarz, przymuszony nagłym brakiem funduszy, nie wahał się zwrócić nawet do żony wydawcy, Lorentyny Dembowej. W jednej z przesłanych jej wiadomości uprzejmie informuje, że Demby zobowiązał się tego konkretnego dnia przekazać mu 10 rubli, a ponieważ wydawca pracuje aż do piątej, Przybyszewski nie może czekać i zwraca się po należną sumę ${ }^{33}$. Zdarzało się, że pisał do Dembowej, błagając o zaliczkę - liczył zapewne na większą litość ze strony kobiety, niż przyzwyczajonego do wyłudzania pieniędzy wydawcy. Przy tworzeniu dramatu Śnieg skierował do niej list o treści:

Daję Pani słowo honoru, że od dwóch dni zaledwie na herbatę i bułki starczy, może Pani zechce zrozumieć, że w takich warunkach praca niemożliwa, że jestem wprost zmuszony, w ten lub w ów sposób, parę rubli wydostać ${ }^{34}$.

\section{I dodawat:}

Z całego serca pragnę tylko z mężem Pani pozostawać odtąd i nadal w wydawniczych stosunkach, ale głód, prosty idjotyczny głód, mógłby mnie zmusić oddać pracę komu innemu. A przecież ja bajońskich sum nie wymagam ${ }^{35}$.

Łatwo przypuścić, że tego typu korespondencja nie zawsze spotykała się z przychylnością Dembego, a kolejna prośba o zaliczkę musiała zakończyć się spięciem, czego dowodem jest jeden z listów pisarza do wydawcy, w którym peroruje:

Byłem ogromnie zdziwiony Pańskim listem. Pan mego listu zupełnie nie zrozumiał. Ja przecież nie Panu przypisywałem winy, że mam tysięczne przykrości, bo tu piśmiennie poświadczam Panu, że rzadko widziałem wydawcę tak „gentelmanlike”, jak Pan. Zwróciłem się z prośbą do Pana, by mi Pan dopomógł, bym mógł spokojnie pracować i nie mieć tych przykrości życiowych: naprzykład tego, że mi na obiad zabraknie ${ }^{36}$.

W dalszej części listu Przybyszewski zauważył, że nie może dojść do porozumienia z Dembym w sprawie honorarium. Wydawca proponował pisarzowi sto rubli po otrzymaniu manuskryptu, a resztę sumy po trzech miesiącach, nato-

\footnotetext{
${ }^{31}$ Ibidem, s. 277 [List do Stefana Dembego w Warszawie z dnia 6 maja 1902].

32 Ibidem, s. 278 [List do Stefana Dembego w Warszawie z maja-czerwca? 1902].

33 Ibidem, s. 282 [List do Stefana Dembego w Warszawie z dnia 29 lipca 1902].

34 Ibidem, s. 290 [List do Lorentyny Dembowej w Warszawie z maja-lipca 1902].

35 Ibidem.

${ }^{36}$ Ibidem, s. 282 [List do Stefana Dembego w Warszawie z dnia 29 lipca 1902].
} 
miast Przybyszewski upierał się, że miał otrzymać dwieście rubli po przekazaniu manuskryptu i po sto rubli przez dwa miesiące, a więc łącznie czterysta rubli. Z listu wywnioskować można, że problem dotyczył nie tyle wysokości honorarium, ile rat, $w$ jakich miały być one wypłacane. Przybyszewskiemu zależało na szybkim otrzymaniu większej sumy, co argumentował natychmiastową potrzebą odpoczynku i wyjazdu. Swój wywód zakończył słowami: „Niech się więc Pan nie dziwi, że ja przynaglony warunkami życia, będę się musiał zgłosić do innych wydawców, którzy większą sumę od razu mi wypłacą"37. Rzeczywiście, jak zapowiedział, tak uczynił i dramat Matka, o którym wówczas rozpisywał się w listach, wyszedł ostatecznie spod prasy Księgarni Polskiej, mimo że w korespondencji znaleźć można wiadomość o pobraniu przez Przybyszewskiego honorarium od Dembego za pierwsze wydanie dramatu w dwóch tysiącach egzemplarzy ${ }^{38}$. W listach brak natomiast wyjaśnienia, dlaczego utwór ostatecznie trafił do innego wydawcy.

Kolejnym tekstem, który Przybyszewski miał złożyć w wydawnictwie Dembego, był dramat Król. Pisarz ręczył „słowem honoru”, że dostarczy go za miesiąc, jednak dopiero po upływie dwóch przesłał wydawcy informację:

Oddaję niniejszem Panu nowy mój dramat pod tytułem Król pod następującemi warunkami:

1. 50 rubli zaraz,

2. 200 rubli po wręczeniu manuskryptu,

3. 150 rubli miesięcznie ratami po 50 rubli $^{39}$.

Ostatecznie jednak Demby nie wydał tego utworu. Ukazał się on dopiero w 1906 roku w oficynie Alfreda Altenberga we Lwowie pod tytułem Odwieczna baśńn.

Na podstawie listów Przybyszewskiego do wydawcy widać, że często toczyły się pomiędzy nimi rozmowy na temat konkretnych tytułów. Zdarzało się, że pisarz informował o kończeniu prac nad jakimś tekstem albo poświadczał otrzymanie od Dembego honorarium za utwór, który nigdy się u niego nie ukazał. W wielu wypadkach nie wiadomo, co spowodowało, że dzieła te drukowane były u innych wydawców, ponieważ w listach, które pisał Przybyszewski nie ma informacji, które wskazywałyby na przyczyny tej sytuacji. Bardzo prawdopodobne jest to, że większość rozmów toczyła się pomiędzy mężczyznami bezpośrednio; możliwe też, że listy od Dembego do pisarza rzuciłyby nowe światło na tę sytuację.

Przybyszewski obiecywał Dembemu również utwory, które ostatecznie nie zostały przez niego ukończone, czego przykładem jest dramat Srebrne gody. Po entuzjastycznej wiadomości, że za dwa tygodnie tekst będzie dostarczony wydawcy, praca nad sztuką zaczęła się wydłużać. Temat dramatu powrócił dopiero

\footnotetext{
${ }^{37}$ Ibidem.

38 Ibidem, s. 289 [List do Stefana Dembego w Warszawie z dnia 11 września 1902].

39 Ibidem, s. 293 [List do Stefana Dembego w Warszawie z dnia 5 listopada 1902].
} 
po kilku miesiącach, kiedy wspomniała o nim żona pisarza, Jadwiga. W liście do Zdzisława Przybyszewskiego, przyjaciela (niespokrewnionego), opowiedziała:

Stach jest teraz względnie zdrowszy jak przedtem i pije umiarkowanie. Wziął się też w ostatnich dniach do Srebrnych godów, wczoraj pisałam mu do późna w nocy w łóżku, bo już leżałam, jak mu strzeliło dyktować mi. Dotychczas bardzo ładne ${ }^{40}$.

Mimo optymistycznych zapowiedzi, Przybyszewski nigdy nie dokończył Srebrnych godów. Jedna scena została opublikowana w księdze jubileuszowej „Kuriera Porannego”, czego efektem było nieporozumienie ze Stefanem Dembym, który myślał, że pisarz bez jego wiedzy dąży do publikacji utworu na łamach tego czasopisma.

Podobny los spotkał tłumaczenie Wiosny Schlafa, na poczet którego pisarz pobrał 20 rubli, w związku z czym Demby zapowiedział już tę książkę w swoim Katalogu-zakładce w rubryce „Pod prasą”. Tym razem Przybyszewski wywiązał się ze swojego zadania i tłumaczenie dostarczył na czas, z kolei wydawca nie spieszył się z jego opublikowaniem. W jednym z listów tłumacz dopytywał:

[...] niepokoją losy moich tłómaczeń Schlafa, Momberta, Novalisa, które już od trzech lat wzdychają za świattem dziennem, tem więcej mnie to niepokoi, bo doniesiono mi z Warszawy z uroczystem zapewnieniem, że Pan i nakład zwinął. Wprawdzie tómaczenia te są Pańską własnością i mógłbyś Pan takowe odsprzedać innemu nakładcy, ale dla mnie ważna rzecz, ażeby praca moja i to bardzo mozolna, niepozostała w manuskrypcie ${ }^{41}$.

Ze wspomnianych utworów ostatecznie ukazał się tylko przekład Schlafa, w 1907 roku w wydawnictwie Jakuba Mortkowicza, który otrzymał to tłumaczenie po upadku firmy Dembego 42 .

Podczas tworzenia kolejnych utworów Przybyszewski bezustannie słał Dembemu listy z prośbą o zaliczki. Można przytaczać je w większej ilości, schemat jednak był podobny i powielał rozpaczliwe zwroty: „potrzebuję na gwałt”, „grożą mi przykrości”, „zobowiązałem się zapłacić”, „rzeczywiście z głodu zdechnę”. Przypuszczalnie permanentne problemy finansowe pisarza wynikały z jego rozrzutności. Można także przytoczyć anegdotę, którą opisał w jednym ze swoich esejów Tadeusz Boy-Żeleński:

Pewnej nocy w Monachium Przybysz wraca z kawiarni do domu. Naraz słyszy w oddali śpiew, poznaje polski język [...]. To robotnik polski szedł ulicą i śpiewał sobie coś z kujawska. Przybyszewski dogania robotnika, wdaje się z nim w rozmowę, ściska go i w rozczuleniu daje mu swój zegarek i wszystkie pieniądze, jakie miał przy duszy, jakieś osiemdziesiąt marek ${ }^{43}$.

Dodał przy tym:

40 Ibidem, s. 316 [List Jadwigi Przybyszewskiego do Zdzisława Przybyszewskiego z dnia 12 maja 1903].

${ }^{41}$ Ibidem, s. 331 [List do Stefana Dembego w Warszawie z dnia 6 maja 1905].

42 D. Rymsza-Zalewska, Stefan Demby. Ksiegarz..., s. 53.

43 T. Boy-Żeleński, Ludzie żywi, Warszawa 1956, s. 88. 
To bardzo piękne. Ale niech mi kto powie, jak sprawić, aby człowiek z takim usposobieniem nie był w kłopotach? Musiałby chyba minister skarbu chodzić za nim i wkładać mu do kieszeni nowe zegarki i nowe banknoty ${ }^{44}$.

Kwestie finansowe poruszane przez Dembego i Przybyszewskiego nie sprowadzały się jednak tylko do pobierania przez pisarza zaliczek na poczet tworzonych utworów, sam wydawca bowiem nie zawsze był terminowy w wypłacaniu pisarzowi należnych honorariów. W jednym z listów Przybyszewski pisał zaskoczony:

List Pański niezmiernie mnie zdziwił. Mógłbym jeszcze zrozumieć bardzo zirytowany ton Pańskiego listu, gdybym się o zaliczkę dopraszał, ale ja tylko proszę o to, co mi się należy. Od pięciu miesięcy pracuję wyłącznie dla Pana, żyję z dnia na dzień, bo Pan płaci tylko temi małymi sumkami, z któremi nic zrobić nie można i w okamgnieniu się rozchodzą ${ }^{45}$.

Groźby oddania swojego utworu innemu wydawcy były częstym argumentem, po który sięgał pisarz w celu zmotywowania Dembego do wywiązania się ze zobowiązań finansowych:

Nie przysyłając mi większej sumy, pomimo obietnic i pomimo że od dwóch tygodni o nie proszę, stawiasz mnie Pan w położeniu bez wyjścia [...]. Jeżeli więc do dzisiejszego wieczora nie otrzymam od Pana całej pozostałej należytości, będę zmuszony krytycznym położeniem jutro sprzedać dramat za pozostałą sumę byle komu z warszawskich wydawców ${ }^{46}$.

Apele te na ogół kończyły się zgodnie z oczekiwaniami Przybyszewskiego — a więc wypłatą pieniędzy — choć zdarzało się, że mimo gorących zapewnień o chęci utrzymania współpracy z Dembym, przekazywał utwór drugiemu wydawcy. Postąpił tak w przypadku studium $O$ dramacie i scenie. Z korespondencji wynika, że tekst znajdował się już w rękach Dembego, gdy Przybyszewski poprosił o jego użyczenie celem przygotowania się do odczytu. Na miejscu, po udanym wystąpieniu, zdecydował się oddać tekst innemu nabywcy ${ }^{47}$. Swoją decyzję thumaczył słowami:

Znalazł się człowiek, prywatny nakładca, który słysząc mój odczyt Kilka uwag o dramacie, przyszedł dziś do mnie i wręczył mi 100 r. tytułem zaliczki, które byłem zmuszony z radością przyjąć, bo inaczej byłbym z głodu zdechł [...]. I chociaż dałem Panu słowo, że cokolwiek napiszę Panu oddam, byłem wprost zmuszony na te 100 rubli się zgodzić ${ }^{48}$.

Dodał także: „List ten piszę ze względów przyjacielskiej lojalności, bo inaczej nie potrzebowałbym się przed Panem usprawiedliwiać"49. Demby okazał się jednak mniej wyrozumiały, niż oczekiwał pisarz, czego dowodem są dwa listy Przy-

\section{${ }^{44}$ Ibidem.}

45 S. Przybyszewski, Listy, t. 1, s. 292 [List do Stefana Dembego w Warszawie z października 1902?].

46 Ibidem, s. 288 [List do Stefana Dembego w Warszawie z września 1902].

47 Tekst ukazał się nakładem Księgarni Naukowej w Warszawie w 1905 roku.

48 Ibidem, s. 308 [List do Stefana Dembego w Warszawie z maja 1903?].

49 Ibidem. 
byszewskiego pozostające bez odpowiedzi. W końcu, wysyłając kolejny, którego pretekstem była prośba o udostępnienie mu wykonanych przez niego tłumaczeń Schlafa, pisarz dodał: „Dziwię się, że Pan na mój wczorajszy list nic nie odpowiedział, a pisałem go z całem szczerem uczuciem człowieka, któremu trudno, jako nieprzyzwyczajonemu żyć na świecie" ${ }^{\text {. }}$.

W korespondencji wysyłanej Dembemu można znaleźć także prośby Przybyszewskiego o udostępnienie egzemplarzy jakichś książek, celem przygotowania się przezeń do odczytu. Również prośby o wydanie egzemplarzy swoich sztuk dla znajomych lub ludzi zainteresowanych wystawieniem ich na scenie pojawiały się tak często, że zawstydzony pisarz obiecywał: „o st a t n i e, przyrzekam Panu o st a tn i e [egzemplarze]" 51 .

Pisarzowi i wydawcy zdarzało się także omawiać listownie sprawy dotyczące samego druku. Na przykład przy wydawaniu Śniegu literat udzielał szczegółowych instrukcji:

Każ Pan koniecznie wydrukować „drugi tysiąc”. Będzie to dla wydawnictwa Pańskiego poniekąd reklamą a dla mnie moralną satysfakcją, że ten Przybyszewski, którego gwałtownie chcą pogrzebać, żyje i jest tak samo czytany jak przed laty ${ }^{52}$.

Korespondencja pisana przez Przybyszewskiego pełna jest zapewnień o przyjaźni i szacunku, jakimi darzył wydawcę. W jego listach Demby często znajdował podobne zwroty: „Raz jeszcze Kochanego Pana zapewniam o moim najgłębszym szacunku, o wdzięcznej i bezwzględnie szczerej przyjaźni”53. Przykładem tego, że relacje między Przybyszewskim a Dembym rzeczywiście wychodziły poza formalne stosunki, jest nieco zdesperowany i smutny w swym tonie list, który pisarz skierował do właściciela wydawnictwa w dniu swoich urodzin:

Moje przysłowie to już teraz: Jeżeli nikt nie pomoże, to Demby pomoże. Dziś skończyłem 35 rok mego życia, 23 maja tego samego roku będę obchodził jubileusz piętnastoletniej pracy literackiej, wybacz Pan, że się do niego znowu z prośbą zwracam, ale strasznie przykro człowiekowi w tak podniosłych dniach być bez kopiejki, a raczej już drugi dzień bez obiadu [...]. Zrobiłby mi Pan ogromną przysługę, gdyby mi Pan p o ż y c z ył 10 rubli — wyraźnie proszę o pożyczkę, bo się zwracam do Pana, jako do życzliwego mi człowieka, a nie wydawcy ${ }^{54}$.

Tego samego dnia Przybyszewski napisał drugi list, dziękując mu za okazane dobro i życzenia potwierdzające spełnienie prośby przez wydawcę.

Współpraca pomiędzy Przybyszewskim a Dembym zakończyła się w roku 1905, kiedy pisarz zaczął planować przeprowadzkę do Niemiec. Po osiedleniu się w Monachium skierował on do swojego przyjaciela, adwokata i pisarza Kazimierza Sterlinga, list o treści:

\footnotetext{
50 Ibidem, s. 308-309 [List do Stefana Dembego w Warszawie z maja 1903?].

51 Ibidem, s. 315 [List do Stefana Dembego w Warszawie z dnia 22 lipca 1903].

52 Ibidem, s. 316 [List do Stefana Dembego w Warszawie z dnia 25 września 1903].

53 Ibidem, s. 288 [List do Stefana Dembego w Warszawie z dnia 9 października 1902].

${ }^{54}$ Ibidem, s. 306 [List do Stefana Dembego w Warszawie z dnia 7 maja 1903].
} 
Idź do Dembego, przekonaj się, jak tam rzeczy moje stoją. W ustawicznym moim warszawskim transie alkoholowym załatwiałem interesa, a teraz nie mam wyobrażenia, ile pieniędzy pobrałem od Dembego, i jak układ zawarłem co do Śniegu. Demby drukuje drugi nakład Śniegu, nawet mnie o tem nie zawiadomił [...]. To przecież ostatnie łajdactwo rozporządzać się moimi książkami, jakbym ja wcale nie istnia ${ }^{55}$.

Oczywiście na pierwszym wydaniu Śniegu widniała adnotacja: „Dramat Śnieg jest wyłączną własnością wydawcy"56, Demby miał więc prawo rozporządzać utworem.

Trudno jednoznacznie określić charakter relacji między Przybyszewskim a Dembym. Z listów wynika, że późniejszemu dyrektorowi Biblioteki Narodowej zależało na tym, by pisarz mógł bez przeszkód wydawać swoją twórczość i aby dzieła te wychodziły spod pras jego oficyny. Pomiędzy nimi toczyły się rozmowy na temat wielu utworów, jednak ostatecznie ukazał się tylko jeden dramat. Nie przeszkadzało to pisarzowi pobierać zaliczek także na poczet pozostałych.

Sam Przybyszewski wiele pisał o dozgonnej przyjaźni i o szacunku, jakimi darzył Dembego, choć często zapominał o deklarowanej lojalności w chwili, gdy inny nakładca zaoferował mu większą sumę za rękopis. Wydaje się to jednak zrozumiałe, ponieważ pisarz przez większość swojego życia znajdował się w tragicznej sytuacji materialnej. Zachowane listy potwierdzają, że sam Demby nie zawsze wywiązywał się ze swoich obowiązków - Przybyszewski często przypominał, że nie otrzymał jeszcze obiecanej sumy lub w ogóle nie może skontaktować się $\mathrm{z}$ wydawcą. $\mathrm{W}$ jednym $\mathrm{z}$ listów napisał:

Pracuję usilnie od czterech miesięcy — długów pełno — bo życie z dnia na dzień ogromnie męczy, w pracy przeszkadza, Pana nigdy zastać nie mogę - czekałem na Pana przedwczoraj potem wczoraj do 8 -ej wieczorem ${ }^{57}$.

Nie zmienia to jednak faktu, że Demby był wydawcą hojnym i wyrozumiałym, i o ile prośby o zaliczki zazwyczaj spotykały się z jego zrozumieniem i znoszone były z cierpliwością, o tyle sam pisarz nie wykazywał się podobną wyrozumiałością, gdy przychodziło mu poczekać dłużej na swoje honorarium. Rymsza-Zalewska zauważa, że traktował on wydawcę jak „kasę zapomogową, z której czerpał niemal bez ograniczeń" 58 i przytacza słowa Marii Puciatowej o tym, co doprowadziło firmę Dembego do upadku:

Demby nie posiadał zupełnie zmysłu kupieckiego. Chętnie udzielał kredytu, zwłaszcza literatom (klasycznym przykładem jest przypadek Przybyszewskiego) i pozwalał się wyzyskiwać ludziom niesumiennym [...]. Nie chcąc wypuszczać w świat książek niedbale wydrukowanych lub

${ }^{55}$ S. Przybyszewski, Listy, t. 2, s. 400 [List do Kazimierza Sterlinga w Warszawie z dnia 7 października 1906].

56 S. Przybyszewski, Śnieg, Warszawa 1903, http://bc.wimbp.lodz.pl/dlibra/doccontent?id=12210 [dostęp: 18.03.2017].

57 Ibidem, s. 288 [List do Stefana Dembego w Warszawie z dnia 11 września 1902].

58 D. Rymsza-Zalewska, Stefan Demby. Księgarz..., s. 48. 
marnie ilustrowanych, Demby nie liczył się z kosztami. W rezultacie [...] musiał w r. 1905 zwinąć księgarnię, pozostał z uciążliwymi długami, które następnie przez wiele lat, ciężko pracując spłaca1 ${ }^{59}$.

Przybyszewski przeniósł się w 1905 roku do Torunia. Nieznajdujący wsparcia wydawniczego i finansowego u Dembego pisarz, pozostawiony sam z nowym utworem, który nie wpisywał się w idee pozytywistycznej Warszawy, skarżył się w liście do Jana Lorentowicza:

Manuskrypt dramatu mego Śluby obiegał wszystkich nakładców w Warszawie i za każdym razem otrzymałem odmowną odpowiedź. „Takich rzeczy” teraz nie biorą, ich „przekonania” nie pozwalają im wydawać rzeczy, które nie mają społecznego podkładu. To samo w Galicji60.

Problem, o którym pisał w styczniu 1906 roku, po roku wciąż pozostawał aktualny, a w liście do Anieli Pająkówny ${ }^{61}$ pisarz wspominał: „Jam tylko strasznie zdumiony, że j a nie mam nakładcy w Polsce! A taki wstyd mną szarpie, bo, by nagie życie ratować, byłem pokorny i żądałem tak maluczką sumę!"62.

Śluby, poemat dramatyczny w trzech aktach, zadebiutował w końcu książkowo w 1906 roku za sprawą Bronisława Hozakowskiego, z którym Przybyszewski nawiązał kontakt mieszkając w Toruniu (lata 1905-1906). Wydanie przez Hozakowskiego nowego dramatu pisarza okazało się wydarzeniem wzbudzającym sensację wśród znających nakładcę mieszkańców miasta. Henryk Izydor Rogacki tak opisuje to w pracy Żywot Przybyszewskiego: „Na wyjezdnym z Torunia Przybyszewski zrobił numer! Sprzedał Śluby Bolesławowi Hozakowskiemu, tamtejszemu kupcowi, za 650 marek i 30\% czystego zysku w miarę ujawniania wpływów"63. I przytaczał za gazetą „Piast”:

Kiedy po Toruniu rozeszła się wieść, że nakładem Hozakowskiego drukuje się sztukę teatralną jakiegoś Przybyszewskiego, nazywano go filantropem, ponieważ miał odwagę literata wspomagać, gdyż dotąd nakładem Hozakowskiego wychodziły jedynie książki do nabożeństwa i śpiewniki kościelne ${ }^{64}$.

Sfinansowanie przez Hozakowskiego wydania dramatu Śluby musiało być wydarzeniem bez precedensu, zwłaszcza że — jak opisuje Stanisław Helsztyński — był on znany bardziej z działalności kupieckiej, niż wydawniczej. Helsztyński przedstawia go jako znanego w Toruniu kupca, który prowadził firmę „Skład i Hodowla Nasion, Zakłady Ogrodnicze". W działalności wydawniczej Hozakowskiego dominowały więc, obok wspomnianej literatury o charakterze religijnym,

59 Ibidem, s. 17.

${ }^{60}$ S. Przybyszewski, Listy, t. 1, s. 341 [List do Jana Lorentowicza w Warszawie z dnia 7 stycznia 1906].

61 Aniela Pająkówna (1864-1912) — malarka, autorka m.in. Portretu własnego (1892), Zadumanej (1983) czy Autoportretu z córka (1907), matka Stanisławy Przybyszewskiej.

${ }^{62}$ S. Przybyszewski, Listy, t. 1, s. 357 [List do Anieli Pająkówny we Lwowie z dnia 3 lutego 1906].

63 H.I. Rogacki, Żywot Przybyszewskiego, Warszawa 1987, s. 210.

${ }^{64}$ Ibidem. 
głównie katalogi kwiatów, warzyw, nasion i narzędzi rolniczych. Przy zakupie dramatu Przybyszewskiego zastrzegł on sobie prawo własności zarówno do utworu, jak i jego tłumaczeńn 65 .

Przybyszewski słał Hozakowskiemu pomysły dotyczące szaty edytorskiej dramatu Śluby, kiedy już przeniósł się do Monachium w 1906 roku. Pisarzowi początkowo zależało na zaangażowaniu do jej zaprojektowania znanego malarza. Nie miał na myśli nikogo konkretnego, chciał jednak, by było to nazwisko, które podniesie prestiż edycji. Plany te nie powiodły się, gdyż „wszyscy wyfrunęli do Włoszech" 66 . W tej sytuacji poprosił on nakładcę, by okładka była zbliżona wyglądem do tej, która zdobiła poemat dramatyczny Odwieczna baśń wydany przez Altenberga we Lwowie. Śluby ukazały się jednak w 1906 roku w innym formacie

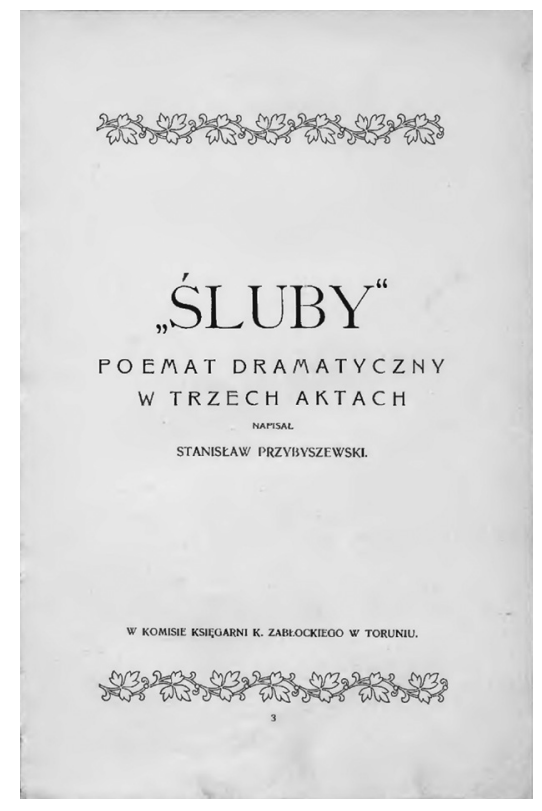

Ilustracja 1. Strona tytułowa dramatu Śluby wydanego w 1906 roku przez Bolesława Hozakowskiego

Źródło: Kujawsko-Pomorska Biblioteka Cyfrowa.

i z inną, niż Odwieczna baśń, okładką, a temat nie został więcej podjęty listownie poza podziękowaniem, które złożył Przybyszewski Hozakowskiemu: „Dziękuję drogiemu Panu za tak pięknie oprawny egzemplarz"67.

${ }^{65}$ S. Przybyszewski, Śluby, Toruń [1906], http://kpbc.umk.pl/dlibra/docmetadata?id=12000\&fro$\mathrm{m}=\&$ dirids=1\&ver_id=\&lp=1\&QI=906A0B1A0409BE77DE8BAF09133E9C92-1 [dostęp: 18.03.2017].

${ }^{66}$ Ibidem, s. 383 [List do Bolesława Hozakowskiego w Toruniu z dnia 5 kwietnia 1906].

${ }^{67}$ Ibidem, s. 385 [List do Bolesława Hozakowskiego w Toruniu z dnia 19 maja 1906]. 
Z korespondencji wynika, że utwór nie trafił do szerokiej publiczności czytelniczej, co wynikało prawdopodobnie z jego słabej reklamy. Na początku roku 1907 Przybyszewski pisał do Hozakowskiego: „Dotychczas rzeczy stoją tak, że faktycznie i bez przesady mało kto wie, że książka wyszła. I to do tego stopnia, że dyrektorzy teatrów są przekonani, że dramat ten istnieje tylko w manuskrypcie"68. Utwór nie przyniósł też większych korzyści ani wydawcy, ani pisarzowi i przez długi czas zalegał na półkach księgarń. Sytuację tego dramatu dokładnie naświetlił w komentarzu do Listów Helsztyński. Z jego relacji wynika, że toruński księgarz Kazimierz Zabłocki, który pośredniczył w rozsyłaniu egzemplarzy księgarniom, odebrał z drukarni dwadzieścia egzemplarzy gratisowych dla siebie oraz czterysta trzydzieśći do dalszej dystrybucji. W maju 1908 roku otrzymał on kolejną partię nakładu tego dramatu, liczącą siedemset dziesięć egzemplarzy. Większość z nich trafiła do sprzedaży komisowej w księgarni Gebethnera i Wolffa. Zarówno podczas wojny, jak i po odzyskaniu niepodległości dramat nie cieszył się dużą popularnością, ani nie był wystawiany na scenie. Helsztyński zauważa, że w 1931 roku na stanie księgarni Gebethnera i Wolffa znajdowało się jeszcze dwieście dziesięć niesprzedanych egzemplarzy, które za sprawą syna nakładcy, Bronisława Hozakowskiego, wróciły w końcu do Torunia ${ }^{69}$. Nie wiadomo, w jaki sposób rozporządził on pozostałym nakładem utworu. Rękopis dramatu przechowywany jest natomiast przez rodzinę Hozakowskiego prawdopodobnie do dziś. Liczy sobie sto pięćdziesiąt osiem kart w formacie $22 \times 26 \mathrm{~cm}$ oprawionych w krochmalny papier popielaty. Karty od piątej do ósmej (tytuł, dedykacja i spis osób) wypisane są ręką Przybyszewskiego, natomiast właściwa treść utworu napisana została przez jego żonę Jadwigę ${ }^{70}$.

Po zadomowieniu się w Monachium Przybyszewski skontaktował się z Wydawnictwem Gebethner i Wolff. Nawiązanie współpracy z tą firmą Helsztyński nazwał ,jasnym promieniem w pomroce monachijskiej”"71 i cytował wypowiedź Eustachego Czekalskiego zamieszczoną na łamach pisma „Nowy Świat”:

Był to może najszczęśliwszy okres w życiu Przybyszewskiego [...]. Powieści jego były tłumaczone natychmiast na język rosyjski. Oryginały ukazywały się na półkach księgarskich Gebethnera i Wolffa, cykle „Mocny człowiek” i „Dzieci nędzy” przez tę firmę dostały się do rąk polskiego czytelnika. Z punktu widzenia interesów materialnych Przybyszewskiego wydania te były dla niego korzystne. Ileż książek jego wzięli za darmo lub za półdarmo wydawcy! Był popularny, modny, rozchwytywany ${ }^{72}$.

Kontakt z wydawnictwem Gebethner i Wolff Przybyszewski zainicjował latem 1908 roku, zwracając się listownie do Józefa Wolffa (1862-1918), syna jednego z założycieli firmy. Zaoferował mu swoją powieść Dzień sądu, będącą drugą

\footnotetext{
68 Ibidem, s. 404 [List do Bolesława Hozakowskiego w Toruniu z dnia 11 lutego 1907].

${ }^{69}$ Ibidem, s. 405.

70 S. Przybyszewski, Listy, t. 2, s. 385.

${ }^{71}$ Ibidem, s. 449.

72 Ibidem.
} 
częścią cyklu Synowie ziemi (pierwszy tom został wydany w 1904 roku przez Księgarnię Polską), życząc sobie za nią honorarium w wysokości tysiąca pięciuset rubli. W odpowiedzi otrzymał jedynie prośbę o wysłanie części manuskryptu, celem opublikowania w „Tygodniku Ilustrowanym”, czasopiśmie społeczno-kulturalnym, którego redaktorem od 1886 roku był Wolff. Przybyszewski jednak stanowczo sprzeciwił się temu pomysłowi, bojąc się, że przepadłaby mu szansa na zarobek ze strony chętnych do tłumaczenia jego utworów Rosjan. Wyjaśnił więc wydawcy:

W Tygodniku Illustrowanym powieść moja nie będzie mogła być drukowaną, a to z tej przyczyny, że Rosyanie [...] z odcinków tłómaczą i nic wtedy już nie płacą. Inaczej zaś sprawa się przedstawia, jeżeli powieść moja wyjdzie równocześnie po polsku i po rosyjsku. Wtedy płacą za każdą moją rzecz jak za oryginał ${ }^{73}$.

Do listu załączył również piąty rozdział wspomnianej powieści. Zarówno tekst, jak i warunki postawione przez pisarza musiały spotkać się z zainteresowaniem wydawców, ponieważ w kolejnym liście Przybyszewski ochoczo zadeklarował, że również gorąco pragnie pozostawać z nimi w stosunkach wydawniczych. Wysokość honorarium uległa jednak zmianie — zmniejszyła się do tysiąca dwustu rubli, na co Przybyszewski przystał. Jeszcze w tym samym liście wrócił on do nawyków znanych już z czasów kontaktów ze Stefanem Dembym, prosząc o dwieście rubli zaliczki à conto honorarium za Dzień sądu, tłumacząc się przy tym fatalną sytuacją materialną i męczącą pięciomiesięczną pracą nad powieścią ${ }^{74}$.

Prośby o zaliczki zaczęły się powtarzać wraz z rozwinięciem się korespondencji pomiędzy Przybyszewskim a Wolffem, a tłumaczenia były podobne do tych, które kierował niegdyś do Dembego, na przykład: „Moich wierzycieli jakby coś opętało, nachodzą mnie ustawicznie"75. Zmieniła się jednak wysokość potrzebnych sum — nie było to już pięć lub dziesięć rubli, tylko zwykle dwieście. Na szczęście dla pisarza Józef Wolff charakteryzował się dużą hojnością — bez problemu udzielał mu wsparcia finansowego, a przy wypłacie honorarium za Dzień sadu odliczył mu od tej kwoty tylko połowę zaliczki ${ }^{76}$.

W międzyczasie Przybyszewski zdążył zmienić zdanie co do opublikowania powieści w „Tygodniku Ilustrowanym” i zgodził się oddać ją redakcji, pod warunkiem, że dostanie za nią taką samą kwotę, jak za wydanie książkowe. Gdy propozycja okazała się nieaktualna, Przybyszewski za zgodą wydawnictwa sam próbował szukać dodatkowego źródła dochodu w innych redakcjach. Obraz tej sytuacji uzupełnia w komentarzu do Listów Helsztyński, wyliczając pisma, które odrzuciły powieść: wspomniany już „Tygodnik Ilustrowany”, „Swiat”, „Kurier Warszawski” oraz „Nowa Gazeta”77.

73 Ibidem [List do Józefa Wolffa w Warszawie z 7 lipca 1908].

74 Ibidem, s. 450 [List do Józefa Wolffa w Warszawie z dnia 28 lipca 1908].

75 Ibidem, s. 451 [List do Józefa Wolffa w Warszawie z dnia 20 sierpnia 1908].

${ }^{76}$ Ibidem, s. 452 [List do Józefa Wolffa w Warszawie z dnia 2 października 1908].

77 Ibidem 
Przy okazji tworzenia kolejnego tomu Synów ziemi Przybyszewski ponownie skontaktował się z Wolffem, przekonując go: „Jeżeli Pan wziął pierwszy tom, nie widzę przyczyny, dla któregoby Pan nie miał wziąć i drugiego". Zapewniał także:

Ten drugi tom pociągnie pierwszy, to stare doświadczenie księgarskie [...]. Ja już wiem, że Pan w zasadzie weźmie wszystko, co napiszę, ale czasami zasada nie wytrzymuje próby, jak to było ostatnio z Godami życia ${ }^{78}$.

Wspomniany dramat, po odrzuceniu przez Gebethnera i Wolffa, Przybyszewski próbował sprzedać oficynie Orgelbrandów. Postawione przez niego warunki to trzysta rubli zaliczki od zaraz, a reszta na procent, jednak wydawcy nie byli zainteresowani jego sztuką. Ostatecznie wydrukowana została rok później nakładem Kasy Przezorności i Pomocy Warszawskich Pracowników Księgarskich. Wydawnictwo Gebethnera i Wolffa odrzuciło także w 1913 roku dramat Miasto, który ukazał się rok później w oficynie Leona Idzikowskiego w Kijowie.

Utworami Przybyszewskiego, które wyszły spod pras Gebethnera i Wolffa, były jeszcze: trylogia Mocny człowiek (wydawana w latach 1912-1913, Przybyszewskiemu udało się wówczas zwiększyć otrzymywane honorarium do tysiąca pięciuset rubli), dramat Topiel (1912), dylogia Dzieci nędzy oraz dramat Mściciel (1927).

Wygląda na to, że współpraca Przybyszewskiego z firmą Gebethner i Wolff układała się nadzwyczaj dobrze — poeta prosił o zaliczki i natychmiast je dostawał. Mało kiedy wywiązywał się ze swoich zobowiązań na czas, w listach więc pisał podobne tłumaczenia: „Wybacz Pan dłuższą zwłokę [...], ale zapadłem na influenzę” albo „trudności kompozycyjne wymagały napisania na nowo dwóch rozdziałów" "79. Wydawnictwo raczej nie ingerowało w samą pracę Przybyszewskiego i pozostawiało mu wolną rękę. Wyjątkiem była sytuacja, w której zasugerowano zmianę tytułu trzeciego tomu Mocnego człowieka. Dzieło zatytułowane zostało przez autora jako Romowe, jednak wydawcy argumentowali, że dla polskiego czytelnika tytuł ten będzie niezrozumiały ${ }^{80}$. Powieść jest więc dziś znana jako Święty gaj. Na wydaniu znalazła się także informacja:

Święty gaj stanowi trzecią i nierozerwalną część, nie trylogii, ale jednolitej powieści, p.t.: Mocny człowiek, którą autor z przyczyn od niego niezależnych, na trzy części rozerwać musiał i w pewnych odstępach czasu wydawał ${ }^{81}$.

W dalszych słowach przekonywał, że tylko zapoznanie się ze wszystkimi częściami powieści może dać czytelnikowi możliwość wyrobienia sobie opinii na temat utworu. Podobna informacja znalazła się także we Słowie wstęnnym poprzedzającym powieść Adam Drzazga, drugą i ostatnią część cyklu Dzieci nędzy. Pojedyncze tomy swoich cykli powieściowych, wydawanych pod różnymi tytułami

78 Ibidem, s. 493-494 [List do Józefa Wolffa w Warszawie z dnia 13 lipca 1910].

79 Ibidem, s. 451 [List do Józefa Wolffa w Warszawie z dnia 20 sierpnia 1908].

80 Ibidem, s. 557 [List do Józefa Wolffa w Warszawie z dnia 22 grudnia 1910].

${ }^{81}$ S. Przybyszewski, Święty gaj, Warszawa 1913, http://dlibra.umcs.lublin.pl/dlibra/doccontent?id=17930 [dostęp: 18.03.2017]. 
i w różnych odstępach czasowych, autor zalecał traktować jakby były dziełami dramatycznymi - poszczególne powieści pełnią funkcję aktów, które zmieniają scenerię utworu, lecz wspólnie tworzą zamkniętą całość. To wyjaśnienie dało mu także okazję do krótkiej wzmianki na temat trudnej sytuacji pisarzy, którzy muszą dzielić swoje utwory na mniejsze fragmenty i wydawać je osobno. „O szczęśliwy Flaubercie, któryś mógł latami całymi nad jedną powieścią pracować zaczemś ją wydał i nie potrzebował jej częściami wydawać!"82 — wzdychał Przybyszewski.

Pisarz często zachwalał współpracę z Wolffem, na przykład: „Nigdy jeszcze z żadnym nakładcą tak miłych i życzliwych nie utrzymywałem stosunków jak właśnie z Panem" 83 . Nic dziwnego, że takie opinie padały ze strony Przybyszewskiego, współpraca z wydawnictwem zapewniła mu bowiem jako literatowi dużą popularność. Przede wszystkim ustabilizowała się jego sytuacja materialna. Istotne znaczenie miał także fakt, że oficyna ta zajmowała wówczas znaczące miejsce na polskiej mapie wydawniczej, wobec czego publikowanie w niej zapewniało nie tylko pieniądze, lecz także rozgłos. Wydawnictwo zapracowało sobie również na tak zwanych autorów własnych, czyli pisarzy, którzy postanowili związać się tylko z tą jedną oficyną lub którzy wydali w niej większość swoich utworów. Do stałych autorów firmy należeli między innymi Bolesław Prus, Henryk Sienkiewicz czy Władysław Stanisław Reymont. O renomie tego wydawnictwa niech świadczy też fakt, że Leopold Staff, wydając własnym nakładem Sny o potędze, zwrócił się do właścicieli firmy Gebethner i Wolff z prośbą o umieszczenie jej nazwy na książce (publikacje wydawane przez autorów własnym sumptem uchodziły wówczas za gorsze) ${ }^{84}$. Wydawnictwo już od początku swojej działalności nawiązywało współpracę z najwybitniejszymi polskimi pisarzami, co — jak zauważa Jan Muszkowski — nie było trudne w czasach, gdy na ziemiach polskich znajdowało się niewielu „przedsiębiorczych, odważnych, a nade wszystko zasobnych" wydawców ${ }^{85}$. Kluczem do sukcesu, który odniosło wydawnictwo, miała być także, zdaniem Muszkowskiego, umiejętność nawiązywania rzeczowej i profesjonalnej współpracy i rozwijania jej w kierunku kontaktów przyjacielskich:

Korespondencja ta [...] rozpoczynana zwykle chłodno, obojętnie i z daleka, jak przystoi na pertraktacje w sprawach handlowych, nabiera przeważnie z biegiem czasu życia i krwi, staje się coraz bardziej osobista, wylewna, serdeczna, przyjacielska, poufna ${ }^{86}$.

Przybyszewskiemu marzyło się, aby wydawcy zdecydowali się opublikować zbiorowe wydanie jego dzieł. W liście do Wolffa pisał: „Przyznam się Panu,

82 S. Przybyszewski, Adam Drzazga, Warszawa 1914, s. VI, http://kpbc.umk.pl/dlibra/docmetadata?id=11949\&from=\&dirids=1\&ver_id=\&lp=1\&QI=9DDA0AB9345B848FC64F44DEDB447F34-15 [dostęp: 21.03.2017].

83 Ibidem, s. 499 [List do Józefa Wolffa w Warszawie z dnia 15 października 1910].

${ }^{84}$ J. Muszkowski, Z dziejów firmy Gebethner $i$ Wolff, Warszawa 1938, s. 77.

${ }^{85}$ Ibidem, s. 59.

${ }^{86}$ Ibidem. 
że szczytem moich marzeń to byłoby to, gdybyś Pan wydał zbiorowe wydanie wszystkich moich dzieł, przejrzanych, poprawionych i w miarę możliwości wykończonych" ${ }^{87}$. Do sprawy wrócił ponownie w listopadzie 1913 roku, pisząc:

Rok przyszły to mój smutny jubileusz 25-io letniej wytężonej pracy, a przedewszystkiem 25-cio letni jubileusz trosk, kłopotów, niedostatku i biedy wszelakiej. Możebyście Panowie w tym roku wydali zbiorowe wydanie wszystkich mych dzieł. Dałoby się to zrobić? ${ }^{88}$

Niestety po raz kolejny otrzymał odpowiedź odmowną. Wydawnictwo argumentowało swoją decyzję ,kiepską koniekturą”89 na rynku księgarskim. Zapewne nie bez znaczenia był problem coraz mniejszego dostępu do papieru, co wymuszało na wydawcach staranniejszą selekcję publikowanych książek.

Wydawnicza idylla Przybyszewskiego zaczęła psuć się w 1913 roku, kiedy wydawnictwo nie przyjęło jego dramatu Miasto. W 1914 roku zaniepokojony Przybyszewski dopytywał, czy ma szansę na publikację kolejnych powieści w tej oficynie. Nie wiadomo dokładnie, jak brzmiała odpowiedź, jednak w kolejnej wiadomości pisarz oznajmił: „I mnie bardzo przykro, że długotrwałe nasze stósunki się rozwiązały" "90. W 1914 roku wyszła spod pras oficyny jeszcze powieść Adam Drzazga będąca drugą częścią dylogii Dzieci nędzy. Wydawcy chcieli w tym czasie także odsprzedać Przybyszewskiemu pozostały nakład jego utworów, wobec czego zmuszony był on szukać nakładcy gotowego przyjąć książki. W liście do wydawców wyznał: „Całkiem nie rozumiem dlaczego na gwałt się moich książek wyzbyć chcecie, ale to już Wasza rzecz. Pewno musicie mieć jakieś ku temu powody"91. Przybyszewski próbował jeszcze nawiązać kontakt z tą firmą rok później, proponując im wydanie swoich czterech nowel, jednak otrzymał odpowiedź odmowną. Zbiór opowiadań zatytułowany Powrót został wydany nakładem Centralnego Biura Wydawnictw N.K.N. w Krakowie.

W 1916 roku Przybyszewski nawiązał listowny kontakt z Jerzym Hulewiczem, redaktorem awangardowego pisma „Zdrój”. Był on także jednym ze współwłaścicieli Spółki Wydawniczej „Ostoja” założonej w 1916 roku w Poznaniu przez jego brata Witolda Hulewicza. Sowiński określił ją jako „ekskluzywną oficynę wydawniczą", która powstała w celu rozszerzenia elitarnego ruchu wydawniczego ${ }^{92}$. Wydawnictwo drukowało książki głównie w seriach „Biblioteka Zdroju” i „Biblioteka Przekładu”, w których znaleźć można było utwory takich twórców, jak Wacław Berent, Jarosław Iwaszkiewicz czy Adolf Nowaczyński ${ }^{93}$.

\footnotetext{
87 Ibidem, s. 522 [List do Józefa Wolffa w Warszawie z dnia 30 grudnia 1911].

${ }^{88}$ Ibidem, s. 597 [List do Wydawnictwa Gebethner i Wolff w Warszawie z dnia 3 listopada 1913].

${ }^{89}$ Ibidem, s. 599 [List do Wydawnictwa Gebethner i Wolff w Warszawie z dnia 28 listopada 1913].

${ }^{90}$ Ibidem, s. 605 [List do Wydawnictwa Gebethner i Wolff w Warszawie z dnia 24 stycznia 1914].

91 Ibidem, s. 609 [List do Spółki Wydawniczej Gebethnera i Wolffa w Warszawie z dnia

92 J. Sowiński, Typografia wytworna, Wrocław 1995, s. 15.

93 Hulewicz Witold, [w:] Słownik pracowników ksią̇ki polskiej, pod red. I. Treichel, Warsza-
} 13 marca 1914]. wa 1972 , s. 344. 
Przybyszewski zwrócił się do Hulewicza z propozycją wydania utworu Szlakiem duszy polskiej:

Jak Panu wiadomo, niema teraz nakładcy w Polsce, [...] Warszawa nie ma papieru. Stała liczba moich czytelników wynosi około czterech tysięcy, za każdą moją książkę otrzymywałem w przedwojennym czasie tysiąc pięćset rubli [...]. Zwracam się do Szanownego Pana [...] by mi zechciał wyrządzić niezmierną przysługę i w zamian za tysiąc marek zaliczki wziąć moją książkę w depozyt aż do czasu, w którym Gebethner i Wolff, stały mój nakładca, swoje normalne nakładnicze czynności będzie mógł podjąć $c^{94}$.

Utwór, o którym mowa w liście, został wydany przez „Ostoję” dwa razy — w 1917 i 1920 roku. O sympatii, jaka narodziła się między wydawcą a pisarzem, świadczyć może fakt, że Przybyszewski zadedykował ten utwór Hulewiczowi („Artyście i obywatelowi Jerzemu Hulewiczowi pracę tę poświęca Autor”95). Ponadto autor Confiteoru nawiązał z Hulewiczem także dłuższą współpracę przy współredagowaniu „Zdroju”. Kolejny tekst Przybyszewskiego, esej Ekspresjonizm, Słowacki i Genezis z Ducha, powstał właśnie za sprawą tej znajomości. Ten doskonale wpisujący się w profil czasopisma tekst opublikowany został jako pierwszy tom serii „Biblioteka Zdroju”.

Kolejnym wydawcą, który wpłynął na losy Przybyszewskiego, był Stanisław Rogala-Lewicki (1853-1933). Pisarz przez pewien czas był dla niego kimś w rodzaju doradcy literackiego prowadzonego przez niego wydawnictwa Lektor. Kontakt między mężczyznami rozpoczął się w styczniu 1917 roku, a już w czerwcu Przybyszewski udzielał Lewickiemu swoich porad:

Biblioteka „Lektora” może się stać istotnym Czynem w dziedzinie naszej sztuki [...]. Tylko trzeba to planowo przeprowadzić! Więc usilnie Panu radzę, by po Alraunie wydać mój Krzyk następnie wspaniały utwór Barbey d’Aurevilly Les diaboliques [...]. Biblioteka Pańska odegra wtedy w piśmiennictwie naszym bardzo ważną rolę — a z punktu widzenia czysto kupieckiego rokuje najpomyślniejsze nadzieje ${ }^{96}$.

Zgodnie z życzeniem pisarza Krzyk został opublikowany w Lektorze, a Przybyszewski zachwalał tę edycję słowami: ,Krzyk jest pięknie wydany i bardzo Panu jestem zobowiązany, żeś go Pan w tak pięknej szacie wydał, a co mnie najwięcej cieszy, że korekta doskonała"97. Dodawał także: „Szkoda, żem już przed dwudziestu laty takiego Lektora nie znalazł"98.

Krzyk sprzedawał się tak dobrze, że Lewicki postanowił wznowić nakład, nie informując o tym pisarza. Wiadomość ta dotarła do Przybyszewskiego, który

${ }^{94}$ S. Przybyszewski, Listy, t. 2, s. 653 [List do Jerzego Hulewicza w Kościankach z dnia 15 lipca 1916].

95 S. Przybyszewski, Szlakiem duszy polskiej, Poznań 1917, http://www.sbc.org.pl/dlibra/doccontent?id=79368 [dostęp: 21.03.2017].

96 Ibidem, s. 730 [List do Stanisława Lewickiego we Lwowie z dnia 4 czerwca 1917].

97 S. Przybyszewski, Listy, t. 3, s. 39 [List do Stanisława Lewickiego we Lwowie z dnia 1 marca 1918].

98 Ibidem. 
wysłał właścicielowi wydawnictwa list informujący go, że nie zgodzi się na drugi nakład powieści za cenę niższą niż dwa tysiące koron ${ }^{99}$. Kwota ta była wyższa od pierwszego wydania o pięćset koron, co doprowadziło do prawdopodobnie pierwszego spięcia pomiędzy autorem a wydawcą. Lewicki nie zgodził się na te warunki, wobec czego to Przybyszewski musiał ustąpić. Dodał jednakże:

Jeżeli [...] żądam za Krzyk 500 koron więcej, jak za pierwsze wydanie, to jedynie dlatego, że po prostu wyżyć nie jestem w stanie, a przecież i Pan sprzedaje książkę znacznie drożej [...]. Ale godzę się na Pańską propozycję [...] — już Pańskiemu uznaniu pozostawiam, czyby jednakowoż nakładnictwo Szanownego Pana nie mogło uwzględnić niesłychanie trudnych warunków, w jakich żyję i mi przynajmniej połowę [...], a więc 250 koron przyznać zechciało ${ }^{100}$.

Obok Krzyku w Lektorze po raz pierwszy wydana została jeszcze ostatnia powieść Przybyszewskiego, Il regno doloroso. Lewicki zatrudniał Przybyszewskiego również do tłumaczeń, między innymi do Listów miłosnych Marii d’Alcoforado.

Po lekturze korespondencji, jaką Przybyszewski prowadził ze swoimi wydawcami wynika, że każda kolejna współpraca układać musiała się jeszcze lepiej, niż poprzednia. Obecnie to Lewicki, a nie Demby czy Wolff, był najlepszym wydawcą, jakiego mógł sobie wymarzyć, o czym zapewniał właściciela Lektora słowami: „Jeżeli kiedyśkolwiek jakiemuś wydawcy bezwzględnie ufałem i w jego najzupełniejszą uczciwość i dżentelmeńskość wierzyłem, to właśnie, i szczerze mogę powiedzieć, je dy n i e, w Pańską" ${ }^{\prime 101}$.

Warto przypomnieć, że czas współpracy zarówno ze „Zdrojem”, jak i Lektorem to okres, w którym działalność polskich wydawnictw była utrudniona. W marcu 1918 roku w liście do Lewickiego Przybyszewski opisywał tę sytuację słowami:

Otóż to właśnie, o co wszystkie zamiary wydawnicze i w Niemczech się rozbijają: brak papieru [...]. Wiem tylko, z jakimi szalonymi trudnościami miała Ostoja i „Zdrój” do walczenia, by wydobyć papier. Zdrój swoim papierem przetrzyma do 1-go października - a co potem — nie wiadomo jeszcze ${ }^{102}$.

W 1922 roku Przybyszewski sprzedał także Lewickiemu prawa do swoich utworów na wieczystą własność za milion marek polskich. Ciekawostką jest, że wersja tej umowy do wiadomości żony pisarza opiewała tylko na pół miliona. Resztą pieniędzy, bez konsultacji z żoną, Przybyszewski postanowił wspomóc swoją córkę, Stanisławę ${ }^{103}$. List, w którym przedstawił Lewickiemu swój pomysł poprzedził adnotacją „,ściśle poufne” i okrasił wyznaniem: „Z żoną moją oczywiście o tym mówić nie mogę ani się nawet słowem jednym zdradzić, jeżeli chcę

\footnotetext{
99 Ibidem, s. 96 [List do Stanisława Lewickiego we Lwowie z dnia 10 lipca 1918].

100 Ibidem, s. 97-98 [List do Stanisława Lewickiego we Lwowie z dnia 25 lipca 1918].

101 Ibidem, s. 98 [List do Stanisława Lewickiego we Lwowie z dnia 25 lipca 1918].

102 Ibidem, s. 38 [List do Stanisława Lewickiego we Lwowie z dnia 1 marca 1918].

103 H.I. Rogacki, op. cit., s. 333-334.
} 
więc memu sumieniu ulżyć i nie niszczyć zdrowia bezsennymi nocami, muszę to potajemnie zrobić i bez jej wiedzy”"104. Dodawał także: „Uważam Pana za absolutnego gentlemana, stąd odnoszę się do Pana z tą iście przerażającą szczerościąa"105. Odpowiedź nadeszła pomyślna dla Przybyszewskiego, chociaż, jak określił Helsztyński, dość cierpka. W komentarzu do Listów znaleźć można treść wiadomości, jaką wysłał wtedy pisarzowi Lewicki:

Jakkolwiek absorbowany jestem obecnie nadmiernymi wydatkami sprawozdawczymi, przeniesieniem punktu ciężkości Lektora do Warszawy, to mimo to wchodzę zupełnie w Pańskie położenie i przesyłam równocześnie mkp 4000, aby ulżyć Jego sumieniu i skrócić „,piekielnie męczący niepokój"'106.

Z inicjatywą opublikowania w Lektorze wydania zbiorowego wyszedł sam Przybyszewski w 1919 roku $^{107}$. Pisarzowi tak bardzo zależało na ponownym wydaniu wszystkich swoich dzieł, że po raz pierwszy nie miał żadnych żądań finansowych, zdając się na Lewickiego. Zapewniał:

Wierzę jak najmocniej, że Pan żadną miarą w niczym mnie nie skrzywdzi i poda mi możliwie dogodne warunki. Ja oczywiście za mało jestem obeznany z wydawniczymi stosunkami w Polsce i obecną kalkulacją kupiecką, bym mógł z góry Panu warunki stawiaćc8 ${ }^{108}$.

Pierwszą publikacją, która weszła w skład wydania zbiorowego dzieł pisarza, był cyk1 Homo sapiens. Okładki zdobiły rysunki Edmunda Johna, polskiego grafika, malarza oraz architekta. W skład serii zatytułowanej Dzieła weszły także utwory: De profundis, Il regno doloroso, Krzyk, trylogia Mocny człowiek, Powrót, trylogia Synowie ziemi, Dzieci szatana, Szopen a Naród oraz dylogia Dzieci nędzy. Fakt wydania przez oficynę Lektor Dzieł Przybyszewskiego jest znaczący i ważny, jednak w porównaniu z tym przedsięwzięciem w wersji niemieckiej (ośmiotomowa seria dzieł Przybyszewskiego „Werke, Aufzeichnungen und ausgewahlte Briefe" publikowana w Igel Verlag Literatur na przestrzeni lat 1990-1999) rezultaty nie są zadowalające. Czytelnicy dostali pośpiesznie przygotowane wydania identyczne z pierwszymi wersjami tych tekstów, nie zostały one bowiem poprawione ani ponownie przejrzane przez krytyków literatury tak, jakby na to zasługiwały.

Pomimo nielicznych przypadków, kiedy Przybyszewski decydował się odsprzedać jakiś utwór innemu wydawcy, nawiązywał zwykle stałą współpracę wydawniczą. Na początku jego kariery w Polsce była to Księgarnia Polska, którą prowadził Bernard Połoniecki we Lwowie. Przybyszewski publikował za jej sprawą swoje dzieła od 1899 roku, czyli niemal od samego przyjazdu do Polski,

104 S. Przybyszewski, Listy, t. 3, s. 146 [List do Stanisława Lewickiego we Lwowie z dnia 20 czerwca 1920].

105 Ibidem.

106 Ibidem, s. 149 [List do Stanisława Lewickiego we Lwowie z dnia 1 lipca 1920].

107 Ibidem, s. 102 [List do Stanisława Lewickiego we Lwowie z dnia 1 października 1918].

108 Ibidem, s. 116 [List do Stanisława Lewickiego we Lwowie z dnia 24 czerwca 1919]. 
aż do 1904 roku. Przybyszewskiemu udało się nawiązać kontakt z warszawskim wydawnictwem Stefana Dembego, a później z firmą Gebethner i Wolff, dzięki której ustabilizowała się jego sytuacja materialna. Kilka utworów wyszło także dzięki uprzejmości Ludwika Zwolińskiego, Józefa Fiszera czy Jerzego Hulewicza. Z niektórymi wydawcami współpraca okazała się jednorazowa, jak w przypadku Księgarni Naukowej (która wydała tekst $O$ dramacie $i$ scenie) czy Książki (Szopen a Naród). Ostatnim ważnym dla Przybyszewskiego przystankiem było wydawnictwo Lektor, które w latach 1923-1929 roku opublikowało edycję dzieł zbiorowych pisarza.

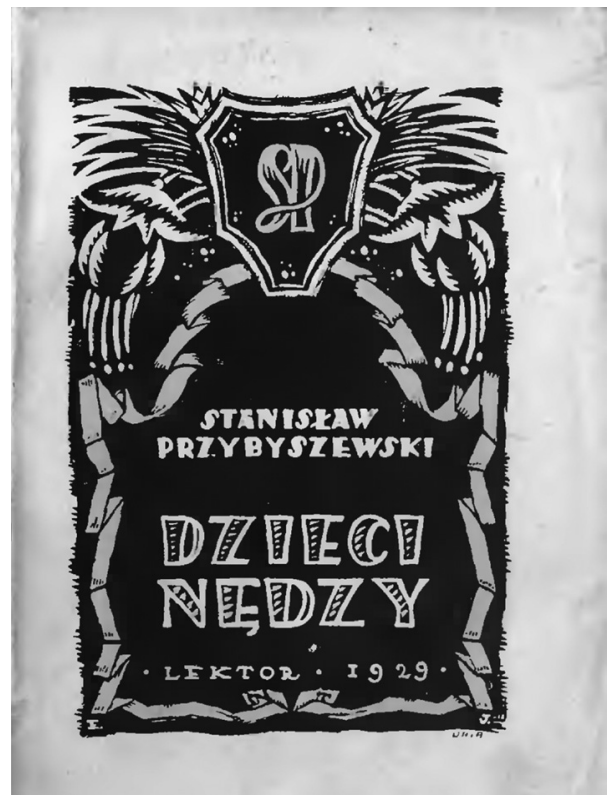

Ilustracja 2. Okładka autorstwa

Edmunda Johna do powieści Dzieci nędzy wydanej przez wydawnictwo Lektor w 1929 roku

Źródło: Zielonogórska Biblioteka Cyfrowa.

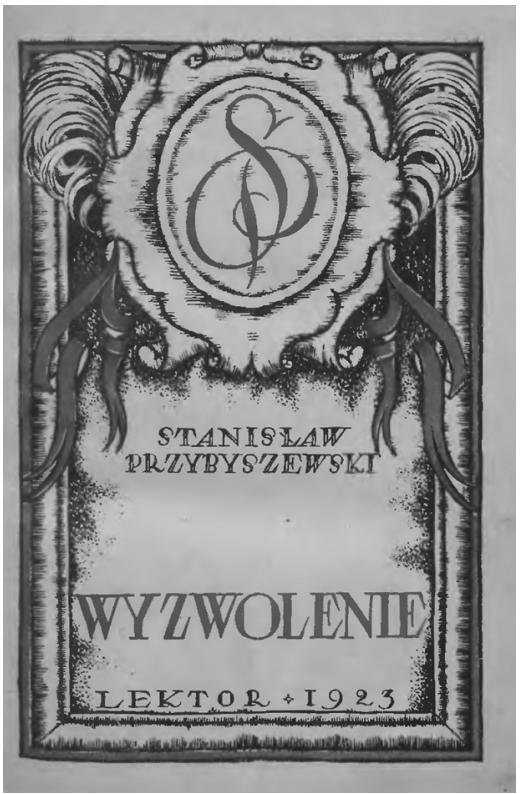

Ilustracja 3. Okładka autorstwa Edmunda Johna do powieści Wyzwolenie wydanej przez wydawnictwo Lektor w 1923 roku Źródło: Pomorska Biblioteka Cyfrowa.

Analizując historię relacji Stanisława Przybyszewskiego z polskimi wydawcami, zauważyć można, że z listów, które kierował on do swoich nakładców, rysuje się obraz pisarza niemal całkowicie uzależnionego od dobrej woli i hojności wydawców. Ze względu na trudną sytuację finansową, w jakiej stale się znajdował, pertraktacje z kolejnymi właścicielami oficyn częściej dotyczyły wysokości honorarium, niż edycji samych utworów. Uwaga pisarza niemal całkowicie skupiona była na sumie, jaką może otrzymać za kolejny utwór i właśnie to — a nie renoma wydawnictwa, stosunek do pisarzy czy dbałość o estetykę wydawnictw 
— przesądzało o nawiązaniu współpracy z konkretną firmą. Często zdarzały się także okresy, w których Przybyszewski nie mógł znaleźć nakładcy dla swojego utworu (jak w przypadku dramatu Śluby), a gdy już pojawiał się ktoś zainteresowany, sprzedawał go bez zastanowienia, nawet jeśli chętnym okazywał się wydający katalogi roślin i kwiatów sprzedawca nasion, a nie prestiżowa oficyna wydawnicza.

Trudno jednak nie zauważyć, że Przybyszewski miał ogromne szczęście, trafiając na nakładców, z którymi udawało mu się związać zawodowo na dłuższy czas. Znajomość ze Stefanem Dembym trwała aż sześć lat, podczas których wydawca regularnie wspomagał pisarza finansowo. Efektem tej relacji jest tylko jeden utwór, Śnieg, wydany jednak z zachowaniem wszelkiej staranności druku, o charakterze bibliofilskim. Podobnie współpraca Przybyszewskiego z firmą Gebethner i Wolff układała się przez wiele lat pomyślnie, czego owocem jest wiele jego dzieł wydanych przez tę oficynę. Trudna do oceny jest natomiast kooperacja pisarza z Lektorem, czyli wydawnictwem Stanisława Lewickiego. Jej efektem są dwie powieści (Krzyk i Il regno doloroso) oraz wydanie dzieł zbiorowych pisarza, których wartość zarówno krytyczna, jak i estetyczna pozostawiają wiele do życzenia.

Dobre przyjęcie pierwszych utworów i wiążąca się z nimi presja, problemy osobiste oraz finansowe sprawiły, że nie tylko przyjaciele, lecz także wydawcy z czasem zaczęli stronić od Przybyszewskiego. Utwory tego modernisty odegrały ważną rolę zarówno w polskiej, jak i niemieckiej literaturze, mimo że jedynie niemieckojęzyczny dorobek uhonorowany został pełnym wydaniem krytycznym, któremu towarzyszyły nowe interpretacje i komentarze. W kraju ojczystym pisarz nie doczekał się tak starannego zbiorowego wydania dzieł, szybko stał się artystą zapomnianym i wspominanym bardziej ze względu na kulturotwórczą i nowatorską rolę, niż faktyczne osiągnięcia w dziedzinie literatury ${ }^{109}$.

\section{Bibliografia}

Album pisarzy polskich (współczesnych), zebrał i objaśnił S. Demby, Warszawa 1901, https://polona.pl/item/1111848/3/ [dostęp: 18.03.2017].

Bernard Poloniecki księgarz lwowski. Dzienniki, pamiętniki i listy z lat 1880-1943, oprac. i wstępem opatrzyła M. Konopka, Warszawa 2006.

Boy-Żeleński T., Ludzie żywi, Warszawa 1956.

Demby S., Listy, oprac. D. Rymsza-Zalewska, Warszawa 2004.

Geszwind J., Kłamstwo Przybyszewskiego i kłamstwa o Przybyszewskim, Lwów 1928.

Historia literatury polskiej w dziesięciu tomach, t. 7, Młoda Polska, red. A. Skoczek, Bochnia 2004. Hutnikiewicz A., Stanisław Przybyszewski. Legenda i rzeczywistość, [w:] idem, Portrety i zarysy literackie, Warszawa 1976.

109 Historia literatury polskiej w dziesięciu tomach, t. 7, Młoda Polska, red. A. Skoczek, Bochnia 2004, s. 29. 
Klukowski B., Stefan Demby —życie petne ksiażek, „Poradnik Bibliotekarza” 2014, nr 10.

Kraśko N., Instytucje wydawnicze w II Rzeczypospolitej, Warszawa 2001.

Maleczyńska K., Książki i biblioteki w Polsce okresu zaborów, Wrocław 1987.

Muszkowski J., Z dziejów firmy Gebethner $i$ Wolff, Warszawa 1938.

Połoniecki B., Ze wspomnień wydawcy, „Prosto z Mostu” 1935, nr 41.

Przybyszewski S., Adam Drzazga, Warszawa 1914, http://kpbc.umk.pl/dlibra/docmetadata $\mathrm{id}=11949 \&$ from $=\&$ dirids $=1 \& v e r \_i d=\& l p=1 \& Q I=9 D D A 0 A B 9345 B 848 F C 64 F 44 D E-$ DB447F34-15 [dostęp: 21.03.2017].

Przybyszewski S., Listy, t. 1, 1879-1906, zebr., życiorysem, wstępem i przypisami opatrzył S. Helsztyński, Gdańsk 1937.

Przybyszewski S., Listy, t. 2, 1906-1917, zebr., życiorysem, wstępem i przypisami opatrzył S. Helsztyński, Gdańsk 1938.

Przybyszewski S., Listy, t. 3, 1918-1927, zebr., życiorysem, wstępem i przypisami opatrzył S. Helsztyński, Wrocław 1954.

Przybyszewski S., Szlakiem duszy polskiej, Poznań 1917, http://www.sbc.org.pl/dlibra/doccontent?id=79368 [dostęp: 21.03.2017].

Przybyszewski S., Śluby, Toruń [1906], http://kpbc.umk.pl/dlibra/docmetadata?id=12000\&fro$\mathrm{m}=\&$ dirids=1\&ver_id=\&lp=1\&QI=906A0B1A0409BE77DE8BAF09133E9C92-1 [dostęp: 18.03.2017].

Przybyszewski S., Śnieg, Warszawa 1903, http://bc.wimbp.lodz.pl/dlibra/doccontent?id=12210 [dostęp: 18.03.2017].

Przybyszewski S., Święty gaj, Warszawa 1913, http://dlibra.umcs.lublin.pl/dlibra/doccontent?id=17930 [dostęp: 18.03.2017].

Rogacki H.I., Żywot Przybyszewskiego, Warszawa 1987.

Rymsza-Zalewska D., Stefan Demby. Księgarz i wydawca, Warszawa 2014.

Rymsza-Zalewska D., Stefan Demby znany i nieznany, Warszawa 2003.

Słownik pracowników ksiązki polskiej, pod red. I. Treichel, Warszawa 1972.

Słowiński J., Topografia wytworna w Polsce 1919-1939, Wrocław 1995.

\title{
Stanisław Przybyszewski's contacts with Polish publishers
}

\author{
Summary
}

In the article the author discusses the presence of the oeuvre of Stanisław Przybyszewski (18681927) on the Polish publishing market. Stanisław Przybyszewski is a representative of Polish modernism. At the turn of the 19th and 20th centuries as well the readers as the literary critics were very interested in his prose, poetic and dramatic creation. This article characterizes the publishing history of Przybyszewski's literary works in Poland from his debut in 1892 to the end of his life in the light of the cooperating with Przybyszewski's publishing companies such as Księgarnia Polska, Gebethner and Wolff and Lektor, and Polish publishers, e.g. Stefan Demby.

KEYWORDS: publishing, Stanisław Przybyszewski, the cooperating with publishers 